\title{
The spillover effects on strategic interdependence neighboring countries: A game theory approach
}

\author{
Oyundelger Sharkhuu ${ }^{1 *}$, Pu Yongjian ${ }^{1}$, Batdelger Tsogt-Ochir ${ }^{1}$ and Tugs Sanjdorj ${ }^{2}$
}

1 College of Economics and Business Administration, Chongqing University, Chongqing 400044, China; oyundelger@ymail.com(O.SH); puyongjian@cqu.edu.cn(P.U); bdg_bdg@yahoo.com(B.TS)

2 College of Business Administration and Humanity, Mongolian University of Science and Technology, Ulaanbaatar 14200, Mongolia; tugssanjdorj@gmail.com

* Correspondence: oyundelger@ymail.com; Tel.: +97699189238

\begin{abstract}
The main aim of sustainable development is to ensure an intelligible and long-lasting balance between the economy, society, and the environment. Sustainable tourism could only be successful if the inter-relationships between all three dimensions are accepted. In the limited number of research analyses, the focus of the research is on competition between tourist countries and destinations. This study has used Game theory to analyze the competition applies time-series data in selected neighboring countries measure of a VAR-based spillover index, developed by [1] to investigate the time-varying relationship between tourism and Gross Domestic Product. Each country analyzed Vector Error Correction (VEC) and Granger analysis to explore the causal short and long-term tourism and use a sample that spans from 1997 to 2019. From the main results of Cholesky, the total spillover index is $59.0 \%$ between Russia and Mongolia which suggests a moderate interdependence among the four variables. Findings indicate that neither China nor Mongolia have a short-run influence on tourism development. China's inbound tourism is affected in the long run by Mongolia's inbound tourism but not vice versa can be explained by the fact that the number of tourists visiting Mongolia would include China in their travels.
\end{abstract}

Keywords: inbound tourism; spillover effect; game theory; sustainable development; neighboring countries, Mongolia

\section{Introduction}

Tourism is one of the dynamic and fastest-growing sectors of the world economy. Tourism is the processes, activities, and outcomes arising from the relationships and the interactions among tourists, tourism suppliers, host governments, host communities, and surrounding environments that are involved in the attracting and hosting of visitors. In 2019, The World Tourism Organization (WTO) claims tourism is currently the world's largest industry with annual revenues of over USD 1.7 trillion. It also employs a number of departures that exceed 1168 and arrivals that exceed 1401 million in 2018. The world tourism data have shown that the total contribution of the Travel and Tourism sector to Gross Domestic Product was USD 8,9 trillion (10.3\% of global GDP) and was 330 million jobs in 2019 [2]. Tourism creates many Asian country's economies, with international tourism receipts exceeding Asia and the Pacific international tourist arrivals by 308 million in 2017 [3]. Although Asia and the Pacific account for 348 million (25\%) of international tourism arrivals, this generates 435 billion (30\%) of international tourism receipts. In 2018, the world's most visited region of Europe steadily grew. Europe received 710 million (51\%) of international tourism arrivals in 2018, this generated USD 570 billion $(39 \%)$ of international tourism receipts [4]. 
Starting September 27, 1980, the World Tourist Organization decided to have world tourism day to foster awareness among the international community of the importance of tourism and its social, cultural political, and economic values. That makes sense when tourism has been also seen as the driving force for regional development. Successful tourism can increase the destination's tourist receipts, income, employment, and government revenues. However, a country is facing a problem of how to attract tourists to revisit and recommend the destination to others because it is related to the success of destination tourism development [5]. The relationship between international tourism and GDP has been studied by many economists and has become an important factor. Over time, researchers have demonstrated in many ways that there is a relationship between international tourism and GDP.

According to [6] showed on economic theory assuming the better a country's income, the more people are able to travel, and the country's economy is well-government with budgets for building tourism destinations and facilities. Therefore, international tourism is assumed to be direct positive relation to income.

A country's competitiveness is undoubtedly one of the most widely used concepts in current economic policies that significance varies in accordance with the benchmark used in the evaluation: whether it be applied to industry or services, cities, regions, or countries. It is a phenomenon that can be evaluated using various methodological approaches. According to [7] the concept of competitiveness involves different focuses which make it difficult for the concepts to be wide-ranging, while at the same time being useful. From a competition standpoint, competitiveness is the capacity to survive and grow sustainably (making profit) in competing or new markets

In recent years, the competition in tourism has intensified between destinations and cities, regions, or nations. The importance of tourism has to earn the national economies is evidenced by the growing competition between tourism destinations. However, it is possible that cross-border cooperation can promote tourist destinations and travel corridors with complementary locations. Partnership countries are geographically close to each other that can be shared infrastructures such as airports, railways, and roads, or if the partner countries are culturally similar such as the same language, comparative religions, and with an exchangeable political background. Moreover, the congestion of tourists in one location can be distributed and spread to other places in order to avoid such congestion, and the economic benefits of tourism can also be disseminated [8].

Regional cooperation for the development and promotion of tourism is receiving more political and economic attention. In the interconnected Southeast Asian region, tourism development has become one of the high-priority development cooperation areas. In 1994, Laos, Cambodia, Myanmar, Thailand and Vietnam have agreed to jointly market themselves as "Five Countries, One Destination" in a move to promotes development through trade, investment, and tourism from within and outside the sub-regions and integrate their tourism industries in Association of Southeast Asian Nations [9].

Mongolia is a big country situated in Central East Asia, and boarding with Russia and China. It has as territory of $1,564,116$ square kilometers and its official capital is Ulaanbaatar that is a cultural center and it is more attractive for visitors. Mongolia is a relatively unknown destination compared to other popular places in Asia and receives relatively low international tourist arrivals. This is a huge potential for tourism development, but it is also evident in the vast natural beauty of the country, which is rich in wildlife and flora.

Table 1. The top countries of international tourist arrivals in Mongolia from 2015 to 2019

\begin{tabular}{cccccc}
\hline & $\mathbf{2 0 1 5}$ & $\mathbf{2 0 1 6}$ & $\mathbf{2 0 1 7}$ & $\mathbf{2 0 1 8}$ & $\mathbf{2 0 1 9}$ \\
\hline China & 145,029 & 131,312 & 142,481 & 163,979 & 168,298 \\
Russia & 70,668 & 84,065 & 106,885 & 129,095 & 141,927 \\
Korea & 47,213 & 57,587 & 74,921 & 84,184 & 101,279 \\
Japan & 19,277 & 19,985 & 22,519 & 20,990 & 24,419 \\
Germany & 8,992 & 9,709 & 10,582 & 10,819 & 12,405 \\
France & 7,989 & 9,026 & 10,038 & 9,773 & 10,572 \\
United Kingdom & 6,148 & 6,161 & 5,996 & 5,905 & 5,931 \\
\hline
\end{tabular}

Source: National Statistical Office of Mongolia.

In 2019, Mongolia received 636,900 international tourist arrivals. In 2019, travel and tourism sector accounts for $11 \%$ of Mongolia's gross domestic National Statistical Office of Mongolia. Table 1 shows the number of international tourist arrivals in Mongolia between 2015 and 2019. International tourist arrivals in Mongolia from China were 168.298, followed by Russia with 141.927.

In 2017, the United Nations' World Tourism Organization named the tourism sector as the world's third largest export category with USD 1.3 trillion. That year, Mongolia received about 542.000 foreign visitors, of which 469.300 were tourists. As the number of tourists in 2017 increased by 16.1 percent compared to 2016, Mongolia is considered 
as one of the leading countries by tourism revenue, according to UNWTO [10]. The long term development policy of Mongolia titled "Vision - 2050" has 9 fundamental goals and 50 development targets and focuses on the vision of "Mongolia becoming a leader with its economic growth, social development and a country that achieved sustainable preservation of its nature, language, territorial integrity, and culture". Mongolia will (1) increase domestic travel in Mongolia and increase the number of foreign tourists to one million annually, (2) promote sustainable development of tourism, (3) develop tourism infrastructure and develop ecologically, special interest and cross-border tourism, and (4) develop eco-tourism regions and products compliant with environmental and health requirements [11]. The Mongolian government focuses on which country or continent can cooperate with tourism development strategy. Then industry follows on providing competitive products, marketing those products, and conducting pricing strategies, while the government provides infrastructure, regulates tourist arrival, and helps the industry in the promotion.

Against this background, this study's main questions are what is the best reaction for each country? and whether or not how Mongolian neighboring countries of China's GDP and Russia's GDP change influences Mongolian tourism in the long term. The paper has set up matrix tables using time series data of tourists from neighboring countries with tourism in a three countries during the 23 year period 1997-2019. In this study, the 2x2 matrices were set up for two key players: player 1 China (CHN), player 2 Mongolia (MNG) and player 1 Russia (RUS), player 2 Mongolia (MNG).

\section{Literature Review}

In 1944, Von Neumann and Morgenstern founded the field of game theory book Theory of Games and Economic Behavior. They were in search of a more effective way of solving certain kinds of economic problems to account for the presence of others who are making decisions in accordance with their own best wishes [12]. Game theory is the study of optimal behaviors and helps solve many problems in various fields of science. It is a branch of applied mathematics that is used in the social sciences especially economics. In economics and philosophy, researchers use game theory to help understanding good or proper behavior.

A game describes that set of players and set of strategies available to those players, and a specification of payoffs for each combination of strategies. Game theory attempts mathematically to behave in a strategic situation where the success of an individual's choice depends on the choices of others. Most economic applications of game theory use the concept of Nash equilibrium [13].

The game theory relies upon mathematical calculations and is used to predict an outcome based on interactions among multiple parties. The theory is reliant upon independent decision-making of individuals [14]. Game theory mainly studies decision-making behavior indirect interaction, that how the participants use the information that they have mastered to make a decision, and the equilibrium solution of this decision-making, which reflects the participants' actions and interactions between the conflict, competition, coordination, and cooperation in the game [15]. Game theory can be divided into non-cooperative games (Nash Equilibrium) and cooperative games [16]. Game theory studies the decision-making principles of many interdependent parties. Players choose from a variety of winning strategies. Winnings can be anything from money to profits to penalties. The player tries to maximize the winnings. The principle of the game theory is not to underestimate the player, but to get a real guaranteed victory with a strategy of surprise and forgetfulness.

The use of a powerful framework of game theory enables managers to systematically analyze the ties among interactions between actors in a market and develop appropriate competitive strategies. There must be a balance between simplifying a problem in a complex world to make it manageable and retaining enough complexity to make it relevant [17].

A game has two players or more, each player assumed to be rationally self-interested, seeking the highest possible benefit. The key requirements of a game theory analysis are determining: (1) the structure of the game, and (2) the payoffs. The structure of the game is the set of strategies available to each player. A strategy is a player's complete plan of action at each decision point to the end of the game. The payoffs available to each player for each strategy, given the other players' strategies, represent the benefit the player achieves at the completion of the game. The outcome of the game is determined by finding the Nash equilibrium. Nash equilibrium is the predicted strategy for each player that is the best response to the predicted strategy of all other players [18].

Researchers decided to study tourism by choosing the application of Game Theory. The mixed strategy pricing behavior package tour using summer season's data from 1982 to 1995 is investigating whether variances differ at different times during the season and thus differ systematically with the level of demand [19]. Liang and Yang [20] studied factors influencing the development of regional tourism cooperation and competition that are interrelated. Empirical study has explored the advantages and disadvantages of cooperation games and competition games, the 
method of cooperation-competition game is utilized. The first choice is the cooperation-competition strategy tactics that can regional tourism activities development.

The macroeconomic variables included relative prices, nominal exchange rates, and world income per capita identify in tourism demand. The results get from this journal is positive and significant between tourism demand and GDP [21]. The study identifies the factors that affect the destination choice process. Co-integration analysis and error correction models (ECMs) to estimate the long-run tourism demand and to forecast European tourism demand [22].

Recently, several studies [23,24] examined applying time-series analyses of the competition between tourist country destinations. Therefore, this research reveals the country indicators have not influenced each other in the short term but in the long term, inbound tourism of China will depend on the inbound tourism of Japan [23]. There was no Nash equilibrium of a payoff for the two countries [24]. Game theory was used in order to analyze the protection of tourist consumers' rights and interests. The study results are significant to the protection of tourist consumers' rights and interests [25].

Several tourism researchers have attempted to clarify the spillover effect on tourism. Yang and Wong [26] investigate and estimate the spillover effects in inbound and domestic tourism flows. The results confirm the existence of spillover effects in both inbound and domestic tourism flows and suggest that physical infrastructure factors, tourist attractions. Researchers employ the spillover effect stated the relationship between tourism and economic growth in selected European countries. This research investigates that the tourism-economy relationship is not stable over time for all countries in terms of both its magnitude and direction [27]. Furthermore, there are spillover effects of shocks to sentiment and mood on outbound tourism demand, although not of high magnitude at all times [28]. Couto et al. [29] also report on research an in-depth perception of the main issues about how this pandemic crisis affects the tourism expectations of residents, and consequently, how this situation will influence regional sustainable development.

\section{Materials and Methods}

This present study uses normal form games to determine the outcomes. That is, the game displays the strategies for each player and the payoffs for each combination of the players' strategies, in a matrix where the first number of international tourism represents the payoff for Player 1 given Player 2's strategy, and the second number of international tourism represents the payoff for Player 2, given Player 1's strategy.

A game model with countries and their strategies can be formulated $\mathrm{A}$ and $\mathrm{B}$, winning function are $f_{1}$, and $f_{2}$ Equation (1), as follows:

Where:

$$
\begin{gathered}
f_{i}=A_{1} x_{2} \rightarrow R, \quad i=1,2 \\
A_{1}=\left\{\alpha_{1}, \alpha_{2}, \ldots, \alpha_{m}\right\}, \quad A_{2}=\left\{\beta_{1}, \beta_{2}, \ldots, \beta_{n}\right\},
\end{gathered}
$$

$\alpha_{i}$ - Player $1^{\prime}$ strategy, $\mathrm{i}=1,2, \ldots, \mathrm{m}$

$\beta_{\mathrm{j}}$ - Player $2^{\prime}$ strategy, $\mathrm{j}=1,2, \ldots, \mathrm{n}$

When the pair of strategies $\left(\alpha_{i}, \beta_{j}\right)$ is chosen, the payoff to the first player is $f_{1}\left(\alpha_{i}, \beta_{j}\right)$ and the payoff to the second player is $\mathrm{f}_{2}\left(\alpha_{\mathrm{i}}, \beta_{\mathrm{j}}\right) ; f_{1}, f_{2}$ are called payoff functions. Matrix $\mathrm{A}$ is called a payoff matrix for player 1 and matrix $\mathrm{B}$ is called a payoff matrix for player 2 Equation (2), as foloows:

$$
\mathrm{A}=\left(\begin{array}{cccc}
\alpha_{11} & \alpha_{12} & \ldots & \alpha_{1 \mathrm{n}} \\
\alpha_{21} & \alpha_{22} & \ldots & \alpha_{2 \mathrm{n}} \\
\ldots & \ldots & \ldots & \ldots \\
\alpha_{\mathrm{m} 1} & \alpha_{\mathrm{m} 2} & \cdots & \alpha_{\mathrm{mn}}
\end{array}\right)
$$$$
B=\left(\begin{array}{cccc}
\beta_{11} & \beta_{12} & \cdots & \beta_{1 \mathrm{n}} \\
\beta_{21} & \beta_{22} & \cdots & \beta_{2 \mathrm{n}} \\
\cdots & \cdots & \cdots & \cdots \\
\beta_{\mathrm{m} 1} & \beta_{\mathrm{m} 2} & \cdots & \beta_{\mathrm{mn}}
\end{array}\right)
$$

The pair of strategies $\left(\alpha_{i *}, \beta_{j *}\right)$ is called an equilibrium point, if

$\mathrm{f}_{1}\left(\alpha_{\mathrm{i} *}, \beta_{\mathrm{j} *}\right) \geq \mathrm{f}_{1}\left(\alpha_{\mathrm{i}}, \beta_{\mathrm{j} *}\right)$

$\mathrm{f}_{2}\left(\alpha_{\mathrm{i} *}, \beta_{\mathrm{j} *}\right) \geq \mathrm{f}_{2}\left(\alpha_{\mathrm{i}}, \beta_{\mathrm{j} *}\right)$

Where: $\left(i^{*}, j^{*}\right)$ is pure strategy of Nash equilibrium point.

Table 2 Payoff matrix between China and Mongolia

\begin{tabular}{llll}
\hline & & China & \\
\hline \multirow{3}{*}{ Mongolia } & Enter tourist & Withhold tourist \\
& Enter tourist & MNG, CHN & MNG, CHN \\
& Withhold tourist & MNG, CHN & MNG, CHN \\
\hline
\end{tabular}


Table 3 Payoff matrix between Russia and Mongolia

\begin{tabular}{llll}
\hline & & Russia & \\
\hline \multirow{3}{*}{ Mongolia } & Enter tourist & Withhold tourist \\
& Enter tourist & MNG, RUS & MNG, RUS \\
& Withhold tourist & MNG, RUS & MNG, RUS \\
\hline
\end{tabular}

The players involved in this game between China(CHN) and Mongolia(MNG), Russia (RUS) and Mongolia (MNG). Each country has two strategies either to enter or withhold tourism. In the case of this study, both are four possible action profiles that measured GDP. Table 2,3 shows that scheme yields the payoff matrices. Those countries are neighboring countries of Mongolia and geographically close to each other. China with Mongolia and Russia with Mongolia are involved in a bi-matrix game; this paper assumes each country shares a common goal which is to reach a sound regional international tourism growth in Central Asia. A sound tourism partnership with countries within the region is a prerequisite for ensuring sustainable market tourism in the future.

In this study, we use the spillover index by Diebold and Yilmaz [1], which is the influence between neighboring countries' tourism and their interrelationships. Spillovers allow for the assessment of the interlinkages between the variables under examination. The spillover index is based on the Vector Auto-Regressive (VAR) model developed by $[30,31]$ the notion of variance decompositions. The idea of an index is simple and straightforward because the analysis of the index is based on the error variance, which is a general concept of the VAR model with $\mathrm{N}$ variables. Specify, the error variance of any variables $(i)$ and other $(j)$ variables that is due to shocks to $(i \neq j)$ for $(i=1,2, \ldots N)$ to calculate the total effect.

The total spillovers represent the average contribution of spillovers of shocks across variables to the total forecast error variance. Put it simply, total spillovers measure the average level of interdependence among the variables under examination. To simplify the notation, consider a simple VAR model with two variables and one lag Equation (3), as follows:

$$
\mathrm{x}_{\mathrm{t}}=\Phi \mathrm{x}_{\mathrm{t}-1}+\varepsilon_{\mathrm{t}}
$$

Where: $\mathrm{x}_{\mathrm{t}}=\left(\mathrm{x}_{1 \mathrm{t}} \mathrm{x}_{2 \mathrm{t}}\right)$ and $\Phi$ are $2 \mathrm{x} 2$ matrix. Convert the moving average representation of the VAR model can be Equation (4) written as follows:

Where: $\Theta(L)=(I-\Phi L)^{-1}$

$$
\mathrm{x}_{\mathrm{t}}=\Theta(\mathrm{L}) \varepsilon_{\mathrm{t}}
$$

The structural moving average representation form can be Equation (5) written as follows:

$$
x_{t}=A(L) u_{t}
$$

Where: $A(L)=\Theta(L) Q_{t}^{-1} ; u_{t}=Q_{t} \varepsilon_{t} ; E\left(u_{t} u_{t}^{\prime}\right)=I$ and $Q_{t}^{-1}$ is the unique lower-triangular Cholesky factor of the covariance matrix of $\varepsilon_{t}$. Considering assumptions can be Equation (6) written as follows:

$$
\mathrm{x}_{\mathrm{t}+1}=\Phi \mathrm{x}_{\mathrm{t}}
$$

The corresponding error variance and covariance matrix after one generation can be Equation (7) written as follows:

$$
\begin{gathered}
e_{t+1, t}=x_{t+1}-x_{t+1, t}=A_{0} u_{t+1}=\left[\begin{array}{ll}
a_{0,11} & a_{0,12} \\
a_{0,21} & a_{0,22}
\end{array}\right]\left[\begin{array}{l}
u_{1, t+1} \\
u_{2, t+1}
\end{array}\right] \\
E\left(e_{t+1, t} e_{t+1, t}^{\prime}\right)=A_{0} A_{0}^{\prime}=\left[\begin{array}{ll}
a_{0,11} & a_{0,12} \\
a_{0,21} & a_{0,22}
\end{array}\right]\left[\begin{array}{ll}
a_{0,11} & a_{0,21} \\
a_{0,12} & a_{0,22}
\end{array}\right]
\end{gathered}
$$

Where $x_{1 t}$ denotes the forecast error variance after one generation is $\mathrm{a}_{0,11}^{2}+\mathrm{a}_{0,12}^{2}$ and $x_{2 t}$ denotes the forecast error variance after one generation is $a_{0,21}^{2}+a_{0,22}^{2}$. Thus, the variance decomposition allows us to split the forecast error variance of each variable into parts attributable to the various system shocks. That $x_{i}(i=1,2)$ variable forecast error variance after one generation effect own $x_{i}$ variable's shock is own variance shares. Other variables of $x_{j}(i, j=1,2 ; j \neq i)$ effect cross variance shares in shock called spillover. In this case, there are two different spillovers.

First, $\mathrm{x}_{1 \mathrm{t}}$ variable's forecast error variance $\mathrm{x}_{2 \mathrm{t}}$ shock effect spillover $\mathrm{a}_{0,12}^{2}$ another is $x_{2 t}$ variable's forecast error variance $x_{1 t}$ shock effect spillover $a_{0,21}^{2}$. The total spillover is $a_{0,21}^{2}+a_{0,21}^{2}$. By expressing this spillover, i.e. the total forecast error variation, relative to the total forecast error variation, it can be converted into an easily 
interpretable index by expressing this spillover $a_{0,11}^{2}+a_{0,12}^{2}+a_{0,21}^{2}+a_{0,22}^{2}=\operatorname{trace}\left(A_{0} A_{0}^{\prime}\right)$. Hence, we are able to construct the total spillover index, Equation (8), as follows:

$$
\mathrm{S}=\frac{\mathrm{a}_{0,12}^{2}+\mathrm{a}_{0,21}^{2}}{\operatorname{trace}\left(\mathrm{A}_{0} \mathrm{~A}_{0}^{\prime}\right)} \times 100
$$

The crucial improvement achieved by using the generalized VAR framework lies in the fact that we are now able to identify the directional spillovers, i.e. we can decompose the total spillover to those coming from and to each observed asset [32]. Furthermore, $p$ lag, $\mathrm{N}$ variables of VAR model forecast spillover index, is computed Equation (9), as follows:

$$
\mathrm{S}=\frac{\sum_{\mathrm{i}, \mathrm{i}=\mathrm{i}}^{\mathrm{N}} \mathrm{a}_{0, \mathrm{ij}}^{2}}{\operatorname{trace}\left(\mathrm{A}_{0} \mathrm{~A}_{0}^{\prime}\right)} \times 100=\frac{\sum_{\mathrm{h}=0}^{\mathrm{H}-1} \Sigma_{\substack{\mathrm{i}, j=1 \\ \mathrm{i} \neq j}}^{\mathrm{N}} \mathrm{a}_{\mathrm{h}, \mathrm{ij}}^{2}}{\Sigma_{\mathrm{h}=0}^{\mathrm{H}-1} \operatorname{trace}\left(\mathrm{A}_{0} A_{0}^{\prime}\right)} \times 100
$$

The spillovers allow us to measure the level of interdependence among variables. The paper employs a time series model to establish the payoff schedule. The most importantly, their use may suggest solutions to bias problems caused by unobserved heterogeneity, which is a common problem in configuring models with cross-sectional data sets. The second reason may be that it is possible to use a data set to detect dynamics that are difficult to detect with cross-sectional data. VAR method assumed that all of the variable in the model must be the lack of autocorrelation and homoscedasticity. The lag length selection when using a minimalvalues of the Akaike and Schwarz information criteria was obtained.

This study also employs Vector Error Correction (VEC) to describe this phenomenon. Applying the Granger-causality test is the most effective and practical way to test the direction of causality [33,34]. According to Engel and Granger [35] theorem, if two variables y and $x$ are co-integrated, then the relationship between the two can be expressed as an (Error Correction Mechanism) ECM in which the error term from the Ordinary Least Square regression, lagged once, acts as the error correction term.

Gross domestic product is the market value of total production of goods and services in a country. Data on GDPs was obtained from the World Bank's World Development Indicators covers the period 1997-2019. The tourism demand is measured by the tourism receipt China and Mongolia (Russia and Mongolia) in year t. Data collected from the World Tourism Organization (UNWTO).

\section{Results}

The descriptive statistics on tourism from China, Russia, and Mongolia results are shown in Table 4. The mean values simply tell the average value for each of the variables. The standard deviation implies the deviation from the sample mean with respect to each of the variables. The Skewness value shows that all variables mirror a normal distribution. The Kurtosis values mirror normal skewness and platykurtic because clearly lower than the value of 3 which implies the thickness of flatness of the distribution of a series. The Jarque-Bera statistic measures the difference of the skewness and kurtosis of the series and test is that the distribution is normal.

\begin{tabular}{|c|c|c|c|c|c|c|}
\hline & \multicolumn{2}{|c|}{ China } & \multicolumn{2}{|c|}{ Mongolia } & \multicolumn{2}{|c|}{ Russia } \\
\hline & GDP & Tourism & GDP & Tourism & GDP & Tourism \\
\hline Mean & 29.00449 & 24.12516 & 22.17668 & 18.98141 & 27.51894 & 22.75363 \\
\hline Std. Dev. & 0.962594 & 0.482461 & 0.996812 & 0.852363 & 0.800462 & 0.364305 \\
\hline Skewness & -0.113642 & -0.691059 & -0.185191 & -1.022614 & -0.555218 & -0.599111 \\
\hline Kurtosis & 1.464856 & 1.976023 & 1.388412 & 2.781176 & 1.811945 & 2.349188 \\
\hline Jarque-Bera & 2.307978 & 2.835498 & 2.620466 & 4.054555 & 2.534353 & 1.781822 \\
\hline \multicolumn{7}{|c|}{ ADF Test Null: Unit root (Assumes Individual Unit root processes) } \\
\hline $\begin{array}{ll}\text { First } & \text { difference } \\
\text { constant } & \end{array}$ & -1.9878 & $-4.4504^{* * *}$ & $-3.5814^{* *}$ & $-4.9578^{* * *}$ & $-3.5278^{* *}$ & $-5.9632^{* * * *}$ \\
\hline Constant+trend & -1.2340 & $-6.4698^{* * * *}$ & $-3.5418^{*}$ & $-4.8845^{* * *}$ & $-3.5939^{*}$ & $-5.8554^{* * * *}$ \\
\hline $\begin{array}{l}\text { Second difference } \\
\text { constant }\end{array}$ & $-5.3372^{* * *}$ & $-5.9348^{* * *}$ & $-6.8263^{* * *}$ & $-5.1852^{* * *}$ & $-5.4271^{* * *}$ & $-10.0554^{* * *}$ \\
\hline Constant+trend & $-5.8759^{* * * *}$ & $-5.7823^{* * * *}$ & $-6.7385^{* * *}$ & $-5.0002^{* * *}$ & $-5.2070^{* * * *}$ & $-9.7779^{* * * *}$ \\
\hline
\end{tabular}

Table 4 Descriptive Statistics

Notes: ${ }^{* * * * * * *}$ reject null hypothesis significance at $1 \%, 5 \%$, and $10 \%$ levels respectively. Source: Results obtained by the authors.

Table 4 also shows the results of the ADF unit root test. The variables tested are the logarithm of variables under the period 1997 to 2019. The ADF test for unit root in the first difference shows that the series some are non-stationary both in intercept and trend. Taking the second difference of the series and testing these with and without intercept and trend makes the series stationary. These results indicate that both of series exhibits unit root processes. 
Table 5 Spillover table between China and Mongolia (Russia and Mongolia) from 1997 to 2019

\begin{tabular}{|c|c|c|c|c|c|}
\hline & China GDP & China Tourism & Mongolia GDP & Mongolia Tourism & From Others \\
\hline China GDP & 69.6 & 23.3 & 2.0 & 5.1 & 30.4 \\
\hline China Tourism & 28.0 & 58.4 & 2.0 & 11.6 & 41.6 \\
\hline Mongolia GDP & 50.9 & 13.6 & 32.4 & 3.2 & 67.6 \\
\hline Mongolia Tourism & 17.5 & 23.8 & 6.0 & 52.7 & 47.3 \\
\hline Contribution to others & 96.4 & 60.7 & 9.9 & 20.0 & 186.9 \\
\hline \multirow[t]{2}{*}{ Contribution including own } & 166.0 & 119.0 & 42.3 & 72.7 & $46.7 \%$ \\
\hline & Russia GDP & Russia Tourism & Mongolia GDP & Mongolia Tourism & From Others \\
\hline Russia GDP & 55.8 & 34.2 & 1.3 & 8.6 & 44.2 \\
\hline Russia Tourism & 19.0 & 70.5 & 3.6 & 6.9 & 29.5 \\
\hline Mongolia GDP & 50.3 & 27.9 & 14.4 & 7.5 & 85.6 \\
\hline Mongolia Tourism & 6.7 & 63.1 & 6.9 & 23.4 & 76.6 \\
\hline Contribution to others & 76.0 & 125.2 & 11.8 & 23.0 & 236.0 \\
\hline Contribution including own & 131.8 & 195.6 & 26.1 & 46.4 & $59.0 \%$ \\
\hline
\end{tabular}

Source: Results obtained by the authors.

In Table 5, there is an overview of the results of the spillover analysis between international tourism and GDP for neighboring countries China and Mongolia (Russia and Mongolia) left in this research. We used the spillover results Dyindex ${ }^{5}$ package Davaajargal [36] of E-views 10 Add-ins. For each country, there are the contributions for the forecast error time series, the table cell $i j$ represents the percentage of shock in variable $j$ in the forecast error variance in sector $i$. The contributions to the forecast error variance of time series, in the table of column $\mathrm{j}$ total of the non-diagonal variable of own variable $\mathrm{j}$ represents the total contribution to others. The total spillover index of each sector from the other sectors is shown in the last column of the table.

From the main results of Cholesky, the total spillover index is $46.7 \%$ between China and Mongolia which suggests a moderate interdependence among the four variables. The international tourism explains $28.0 \%$ Chinese tourism, 50.9\% Mongolian GDP, and 17.5\% of Mongolian tourism at the ten-day horizon. The most influential contribution to others variables is China's GDP $96.4 \%$ and China's tourism 60.5\%. The impact of the Mongolian economy is $9.9 \%$ compared to other sectors is small.

The results from Table 5, in the case between Russia and Mongolia, show that the value obtained for the total spillover index is 59.0\%. For these countries, the international tourism explains $19.0 \%$ of Russian tourism, $50.3 \%$ Mongolian GDP, and 6.7\% of Mongolian tourism at the ten-day horizon.

Table 6 Results of Vector Error Correction Estimates for China and Mongolia

\begin{tabular}{cccc}
\hline Cointegrating Eq: & CointEq1 & Cointegrating Eq: & CointEq1 \\
\hline LNCHNGDP(-1) & 1.000000 & LNMNGGDP(-1) & 1.000000 \\
LNCHNTOU(-1) & -0.993045 & LNMNGTOU(-1) & 1.547637 \\
& $(0.16045)$ & & $(0.17562)$ \\
& {$[-6.18926]$} & & {$[8.81226]$} \\
LNMNGGDP(-1) & 0.321308 & LNCHNGDP(-1) & 3.112282 \\
& $(0.10333)$ & & $(0.66865)$ \\
LNMNGTOU(-1) & {$[3.10953]$} & LNCHNTOU(-1) & $-3.65457]$ \\
C & 0.497268 & & $(0.48670)$ \\
& $(0.05354)$ & & {$[-6.35024]$} \\
\end{tabular}

Notes: LNCHNGDP, LNCHNTOU, LNMNGGDP, LNMNGTOU- China GDP, China tourism, Mongolia GDP and Mongolia tourism. Included observations: 20 after adjustments, standard errors in () and t-statistics in []. Source: Results obtained by the authors.

Table 7 Results of Vector Error Correction Estimates for Russia and Mongolia

\begin{tabular}{lclr}
\hline Cointegrating Eq: & CointEq1 & Cointegrating Eq: & CointEq1 \\
\hline LNRUSGDP(-1) & 1.000000 & LNMNGGDP(-1) & 1.000000 \\
LNRUSTOU(-1) & -0.651697 & LNMNGTOU(-1) & -87.85351
\end{tabular}




\begin{tabular}{lrrr}
\hline & $(0.87357)$ & & $(25.3935)$ \\
& {$[-0.74602]$} & & {$[-3.45969]$} \\
LNMNGGDP(-1) & 0.022972 & LNRUSGDP(-1) & 43.53176 \\
& $(0.35215)$ & & $(33.7760)$ \\
& {$[0.06523]$} & & {$[1.28884]$} \\
LNMNGTOU(-1) & -2.018147 & & -28.36950 \\
& $(0.37319)$ & & $(53.6976)$ \\
& {$[-5.40789]$} & $\mathrm{C}$ & {$[-0.52832]$} \\
$\mathrm{C}$ & 25.25466 & 1099.380 \\
\hline
\end{tabular}

Notes: LNRUSGDP, LNRUSTOU, LNMNGGDP, LNMNGTOU- Russia GDP, Russian tourism, Mongolia GDP and Mongolia tourism. Included observations: 20 after adjustments, standard errors in () and t-statistics in []. Source: Results obtained by the authors.

The Vector Error Correction Model in order to depict the long-run and short-run dynamic interactions, as can be seen in Table 6, 7. The presence of cointegration between variables suggests a long term relationship among the variables under consideration. The long run relationship between GDP and Tourist receipt for one cointegrating vector for the between China and Mongolia (Russia and Mongolia) in the period 1997-2019 is displayed (standard errors are displayed in parenthesis). Table A1 indicates that there was a long run impact of Chinese tourism on Mongolian tourism also Mongolian tourism on Chinese tourism $(C(1)=-0.375, P=0.02 \quad)$ and $(C(1)=-0.73, P=0.06)$. Result shows that short run impact between two countries, a Wald test was conducted with two null hypotheses. As a result shows that, the Chi square for both of the above equations were not significant so the null hypothesis were accepted; there is no short term impact of China on Mongolia and vice versa. Table A2 indicates that there was a long run impact of Russian tourism on Mongolian tourism also Mongolian tourism on Russian tourism $(C(1)=-0.939$, $\mathrm{P}=0.000 \quad)$ and $(\mathrm{C}(1)=-0.216, \mathrm{P}=0.418)$. Result shows that short run impact between two countries, a Wald test was conducted with two null hypotheses. As a result shows that, the Chi square for both of the above equations were not significant so the null hypothesis were accepted; there is also no short term impact of Russia on Mongolia and vice versa.

Table 8 Payoff matrix between China and Mongolia

\begin{tabular}{llll}
\hline \multicolumn{3}{c}{ China } & \\
\hline \multirow{3}{*}{ Mongolia } & Enter tourist & Withhold tourist \\
& Enter tourist & $\mathbf{3 . 1 1 / 0 . 3 2}$ & $\mathbf{- 0 . 8 8 / - 1 . 1 3}$ \\
& Withhold tourist & $-2.33,-0.42$ & $-1.58,-\mathbf{0 . 6 3}$ \\
\hline \multirow{4}{*}{ Table 9 Payoff matrix between Russia and Mongolia } \\
\hline \multirow{4}{*}{ Mongolia } & Russia & Withhold tourist \\
& & Enter tourist & $-3.42 /-0.29$ \\
& Enter tourist & $\mathbf{4 3 . 5 3 / 0 . 0 2}$ & $-1.67 / \mathbf{- 0 . 5 9}$ \\
\hline
\end{tabular}

Table 8 payoff matrix shows that if China enters tourist, Mongolia should withhold $(3.11>-2.23)$ and if China withholds, Mongolia should enter $(-0.88>-1.58)$. If Mongolia decides to enter, it will yield several payoffs given China's actions. Mongolia will yield a GDP increase of (3.11) will get the highest payoffs for tourism if China decides to enter inbound tourism. China's strategy to create GDP through tourism will give her several payoffs given other countries' actions. China will take (0.32) from its GDP increase of $\$ 1$ percent in tourism if Mongolia decides to enter the same thing. Therefore, the first quadrant (3.11/0.32) is the unique Nash equilibrium in pure strategies because it is the place where both players receive the highest payoff. If Mongolia enters, China should withhold $(0.32>-0.42)$ and if Mongolia withholds, China should enter $(-0.63>-1.13)$. Therefore, the best response for Mongolia is to do the opposite to China's action. China withholds, that is China restrains tourism to Mongolia as its dominant strategy, no matter what Mongolia's strategies are. There exists no Nash equilibrium in mixed strategies.

Table 9 payoff matrix shows that if Russia enters, Mongolia should withhold $(43.53>-6.56)$ and if Mongolia enters, Russia should withhold $(0.02>-0.15)$. If Mongolia decides to enter, it will yield several payoffs given Russian's actions. Mongolia will yield a GDP increase of (43.53) will get the highest payoffs for tourism if Russia decides to enter inbound tourism. Russia's strategy to create GDP through tourism will give her several payoffs given other countries' actions. Russia will take (0.02) from its GDP increase of $\$ 1$ percent in tourism if Mongolia decides to enter the same 
thing. Therefore, the first quadrant (43.53/0.02) is the unique Nash equilibrium in pure strategies because it is the place where both players receive the highest payoff. The fourth quadrant $-1.67 /-0.59$ is a dominant strategy for Russia because no matter what Mongolia enters or withholds, Russia always gets a higher payoff.

\section{Discussion and Conclusions}

Game theory is applied in many fields, including business, finance, economics, political science, and psychology. Understanding game theory strategies both the popular ones and some of the relatively lesser-known stratagems is important to enhance one's reasoning and decision-making skills in a complex world. The most important economic feature of activities related to the tourism sector is that contributes are a generation of income, employment, and foreign exchange earnings.

In this respect, tourism is one of the fastest-growing industries and a driving force for so many developed and developing economies. Poor countries or regions in decay could be developed through the tourism sector easily. These countries have several common characteristics, it is reasonable to believe that there would be some strategic interdependence in promoting the development of tourism between China and Mongolia (Russia and Mongolia).

As a decision-making tool in conflict situations, the game theory approach is suggested for planning and adopting an optimal strategy. This study has shown that there is Nash equilibrium in this competition between China and Mongolia (Russia and Mongolia).

In terms of economy, tourism development is considered a game in which there is a winner and a loser. In order to win the game, the players should forecast the response of the competitors in the long term strategies. The problem is that any move made by one party in a competitive situation will cause subsequent moves in others and each of those moves will cause further moves. A strategy that might appear successful best upon current figurations of competitor actions may turn out to have different consequences once competitor actions and reactions have taken place. In terms of tourists, the more competitive tourism developments are the better choices become. Game theory is a measure of tourist evaluation and will allow us to determine which nature development direction tourism will take, nature versus nurture. Sustainable tourism will educate consumers on how to protect eco-friendly travel and protecting the environment.

In brief, the study provides evidence that there are spillover effects on income and tourist receipt in neighboring countries' international tourism. The total spillover index between China and Mongolia is (46.7\%), between Russia and Mongolia (50.9\%). The contributions of this study are to apply Game theory to measure both long-term and short-term benefits to analyze the tourism economy. The results of this study indicated between Russia and Mongolia have short-term, but between China and Mongolia have not; both have in the long term. First, the finding that China's inbound tourism is affected in the long run by Mongolia's inbound tourism but not vice versa can be explained by the fact that the number of tourists visiting Mongolia would include China in their travels. The simulation game in this study also indicates that China and Mongolia's strategies are interdependent to each other. With the absence of China tourism, Mongolia's GDP was decreased from 3.11 to -0.88 . With the absence of Mongolian tourism, China's GDP was decreased from 0.32 to -0.42 .

The visa is the result of a joint initiative of the Heads of State of the relevant partner countries to increase regional tourism and provide opportunities for tourists to explore the diversity of East Africa [37]. The Regional Tourism Organization of Southern Africa (RETOSA) is a permanent body of Southern African Development that promoted Univisa. This organization is responsible for the development of tourism in 14 southern African countries [38].

In order to perform an analysis comprising a sample of China, Mongolia, and Russia, data provided by the World Bank and the World Tourism Organization were used. The limit of this study is its assumption that there would be no change in the surrounding reality of international tourism patterns; there would be no wars, political conflicts, terrorist attacks affect tourism, flight accidents, economic crisis, natural and man-made disaster, etc. Additionally, we can classify the countries into sub-groups by geographic or economic reasons and make specific estimations. Future research suggestion is the elaboration of a methodological approach including compatible samples which could allow the use of other variables in the analysis.

Author Contributions: Oyundelger Sharkhuu and Pu Yongjian designed and performed the experiments, derived the models, and analyzed the data. All of the phases of the paper development proper have been reviewed and worked on by the authors. All authors discussed the results and contributed to the final manuscript.

Acknowledgments: The authors would like to thank the anonymous reviewers for their valuable comments and suggestions to improve the quality of the paper.

Conflicts of Interest: The authors declare no conflict of interest. 
Appendix 1 Results of Long Run and Short Run Relationship in VEC for China and Mongolia

\begin{tabular}{|c|c|c|c|c|}
\hline & Coefficient & Std. Error & t-Statistic & Prob. \\
\hline$C(1)$ & -0.375595 & 0.138371 & -2.714395 & 0.0168 \\
\hline$C(2)$ & -0.121722 & 0.208015 & -0.585160 & 0.5678 \\
\hline$C(3)$ & 0.159763 & 0.188982 & 0.845387 & 0.4121 \\
\hline$C(4)$ & -0.268167 & 0.101021 & -2.654558 & 0.0189 \\
\hline$C(5)$ & -0.047584 & 0.118654 & -0.401032 & 0.6945 \\
\hline$C(6)$ & 0.081167 & 0.039944 & 2.032023 & 0.0616 \\
\hline$C(7)$ & -0.730410 & 0.371113 & -1.968162 & 0.0692 \\
\hline$C(8)$ & -0.757282 & 0.557897 & -1.357385 & 0.1961 \\
\hline$C(9)$ & 0.327961 & 0.506850 & 0.647057 & 0.5281 \\
\hline$C(10)$ & -0.211895 & 0.270939 & -0.782077 & 0.4472 \\
\hline$C(11)$ & -0.534151 & 0.318230 & -1.678507 & 0.1154 \\
\hline$C(12)$ & 0.246608 & 0.107129 & 2.301963 & 0.0372 \\
\hline
\end{tabular}

$\mathrm{D}\left(\right.$ LNCHNTOU) $=\mathrm{C}(1)^{*}\left(\right.$ LNCHNTOU(-1) $\quad-0.295128518561^{*}$ LNMNGTOU(-1) $\left.\quad-18.5710083517\right)+$ $\mathrm{C}(2)^{*} \mathrm{D}($ LNCHNTOU $(-1))+\mathrm{C}(3)^{*} \mathrm{D}(\operatorname{LNCHNTOU}(-2))+\mathrm{C}(4)^{*} \mathrm{D}($ LNMNGTOU $(-1))+$ $\mathrm{C}(5)^{*} \mathrm{D}(\mathrm{LNMNGTOU}(-2))+\mathrm{C}(6)$

\section{R-squared}

Adjusted R-squared

S.E. of regression

Sum squared resid

Wald test:

F-statistic

Chi-square
0.577183 Mean dependent var

0.426176 S.D. dependent var

0.099254 Durbin-Watson stat

0.137920

0.5706

0.5575

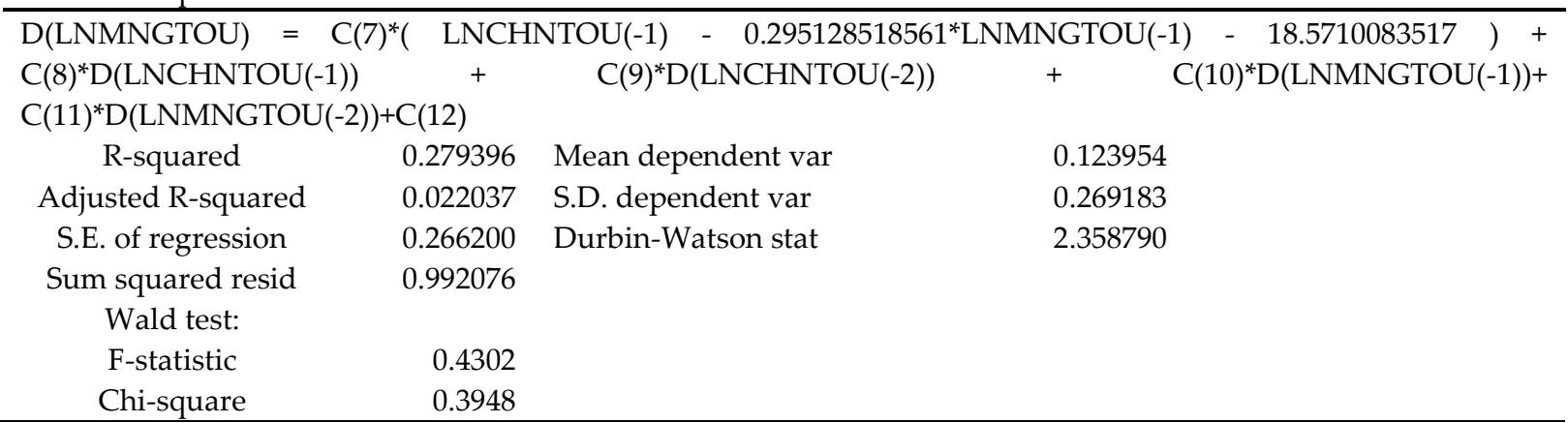

Appendix 2 Results of Long Run and Short Run Relationship in VEC for Russia and Mongolia

\begin{tabular}{|c|c|c|c|c|}
\hline & Coefficient & Std. Error & $\mathrm{t}$-Statistic & Prob. \\
\hline$C(1)$ & -0.939617 & 0.172841 & -5.436296 & 0.0001 \\
\hline$C(2)$ & 0.094579 & 0.159571 & 0.592709 & 0.5628 \\
\hline$C(3)$ & 0.146727 & 0.148217 & 0.989945 & 0.3390 \\
\hline$C(4)$ & -0.377099 & 0.177263 & -2.127341 & 0.0516 \\
\hline$C(5)$ & -0.356469 & 0.136890 & -2.604045 & 0.0208 \\
\hline$C(6)$ & 0.106084 & 0.046237 & 2.294354 & 0.0378 \\
\hline$C(7)$ & -0.216850 & 0.260298 & -0.833084 & 0.4188 \\
\hline $\mathrm{C}(8)$ & 0.059010 & 0.240313 & 0.245556 & 0.8096 \\
\hline$C(9)$ & -0.619272 & 0.223214 & -2.774345 & 0.0149 \\
\hline$C(10)$ & -0.021376 & 0.266957 & -0.080073 & 0.9373 \\
\hline$C(11)$ & -0.090514 & 0.206156 & -0.439054 & 0.6673 \\
\hline$C(12)$ & 0.143977 & 0.069633 & 2.067668 & 0.0577 \\
\hline
\end{tabular}

$\mathrm{D}\left(\right.$ LNRUSTOU) $=\mathrm{C}(1)^{*}\left(\right.$ LNRUSTOU(-1) $\quad-\quad 0.418427194247^{*}$ LNMNGTOU $(-1) \quad-14.7582396897 \quad+$ $\mathrm{C}(2)^{*} \mathrm{D}($ LNRUSTOU $(-1))+\mathrm{C}(3)^{*} \mathrm{D}($ LNRUSTOU $(-2))+\mathrm{C}(4)^{*} \mathrm{D}($ LNMNGTOU $(-1))+\mathrm{C}(5)^{*} \mathrm{D}($ LNMNGTOU(-2) $)+\mathrm{C}(6)$

R-squared

0.736219

0.642012

Adjusted R-squared

S.E. of regression

0.161597

0.365589

Mean dependent var

S.D. dependent var

Durbin-Watson stat

0.018905

0.270084

2.192722

Sum squared resid

Wald test:

F-statistic

0.0803 


\begin{tabular}{|c|c|c|c|c|}
\hline \multicolumn{5}{|l|}{ Chi-square } \\
\hline $\mathrm{D}(\mathrm{LNMNGTOU})=$ & $=\mathrm{C}(7)^{*}(\mathrm{LNRL}$ & $\mathrm{OU}(-1) \quad-\quad 0.4184271$ & VGTOU(-1) & $14.7582396897 \quad$ ) + \\
\hline \multicolumn{5}{|c|}{$\begin{array}{l}\mathrm{C}(8)^{*} \mathrm{D}(\text { LNRUSTOU }(-1))+\mathrm{C}(9)^{*} \mathrm{D}(\text { LNRUSTOU }(-2))+\mathrm{C}(10)^{*} \mathrm{D}(\text { LNMNGTOU }(-1))+\mathrm{C}(11)^{*} \mathrm{D}(\text { LNMNGTOU }(-2)) \\
+\mathrm{C}(12)\end{array}$} \\
\hline R-squared & 0.397730 & Mean dependent var & 0.123954 & \\
\hline Adjusted R-squared & 0.182633 & S.D. dependent var & 0.269183 & \\
\hline S.E. of regression & 0.243364 & Durbin-Watson stat & 2.120389 & \\
\hline Sum squared resid & 0.829162 & & & \\
\hline \multicolumn{5}{|l|}{ Wald test: } \\
\hline F-statistic & 0.1173 & & & \\
\hline Chi-square & 0.0624 & & & \\
\hline
\end{tabular}

Source: Authors own elaboration.

\section{References}

1. Diebold F. X., Yilmaz K. (2009). Measuring Financial Asset Return and Volatility Spillovers, with Application to Global Equity Markets. Economic Journal, pp. 158-171.

2. World Travel and Tourism Council. (2019). ICAO TRIP Symposium - Seamless Traveller Journey: A guidebook. Retrieved from: https://www.icao.int/

3. United Nations World Tourism Organisation. (2017). Tourism Highlights: Retrieved from UNWTO Elibrary.

4. United Nations World Tourism Organisation. (2019). Tourism Highlights: Retrieved from UNWTO Elibrary.

5. Chen, C. F., \& Tsai, D. (2007). How destination image and evaluative factors affect behavioral intentions?. Tourism management, 28(4), 1115-1122.

6. Garin-Munoz, T., \& Amaral, T. P. (2000). An econometric model for international tourism flows to Spain. Applied Economics Letters, 7(8), 525-529.

7. Farina, E. M (2003). The performance of the agricultural business is not the foreign trade and governance of our agricultural production system of Swiss beef. Sao Paulo: FEA / USP.

8. Grundy-Warr, C., \& Perry, M. (2001). Indonesian-Singapore Cooperation. Interconnected Worlds: Tourism in Southeast Asia, 64.

9. Association of Southeast Asian Nations (2017). Retrieved from https://vietnamnews.vn/ society/ 393392/neighbouring- tourism-ministers-promote-regional-travel.html

10. Mongolian News Agency (2019). Retrieved from: https://www.montsame.mn/en/read/175884 02.01.2019

11. Mongolian vision-2050 long-term development policy of Mongolia. Retrieved from: https://www.legalinfo.mn/law/details/15406?lawid=15406 13.05.2020

12. Davis, M. D. (2012). Game theory: a nontechnical introduction. Courier Corporation.

13. Battigalli, P. (1996). Strategic independence and perfect Bayesian equilibria. Journal of Economic Theory, 70(1), $201-234$.

14. Huang, G. Q., Chen, W., Song, H., \& Zhang, X. (2010). Game-theoretic study of the dynamics of tourism supply chains for package holidays under quantity competition. Tourism Economics, 16(1), 197-216.

15. Zhang, W. (1996). Game theory and information economics. Shanghai people's publishing house, Shanghai, 62-66.

16. Von Neumann, J., \& Morgenstern, O. (2007). Theory of games and economic behavior. Princeton university press.

17. Lindstädt, H., \& Müller, J. (2010). Making game theory work for managers. McKinsey Quarterly, 1-9.

18. Gibbons, R. (1992). A primer in game theory.

19. Taylor, P. (1998). Mixed strategy pricing behaviour in the UK package tour industry. International Journal of the Economics of Business, 5(1), 29-46.

20. Liang, Y. H., Yang, X. J., \& Liang, X. J. (2005). The game-theory analysis on regional tourism cooperation and competition. Geography and Geo-Information Science, 2(1), 1-2.

21. Martins, L. F., Gan, Y., \& Ferreira-Lopes, A. (2017). An empirical analysis of the influence of macroeconomic determinants on World tourism demand. Tourism management, 61, 248-260.

22. Ouerfelli, C. (2008). Co-integration analysis of quarterly European tourism demand in Tunisia. Tourism Management, 29(1), 127-137.

23. Tran, X. (2014). Application of Vector Autoregressive Model in Tourism. E-review of Tourism Research, 11.

24. Tavares, J. M., \& Tran, X. (2019). Is There a Strategic Interdependence Between the USA and Canada in the Tourism Sector? An Analysis Using Game Theory. Tourism Planning \& Development, 16(3), 304-317.

25. Tan, X., Chen, Z., Guan, B., Yang, C., \& Wu, G. (2017). Game theory analysis of protection of tourist consumers' rights and interests at lawsuit angle. Journal of Discrete Mathematical Sciences and Cryptography, 20(4), 885-897.

26. Yang, Y., \& Wong, K. K. (2012). A spatial econometric approach to model spillover effects in tourism flows. Journal of Travel Research, 51(6), 768-778. 
27. Antonakakis, N., Dragouni, M., \& Filis, G. (2013). Time-varying interdependencies of tourism and economic growth: evidence from European countries.

28. Dragouni, M., Filis, G., Gavriilidis, K., \& Santamaria, D. (2016). Sentiment, mood and outbound tourism demand. Annals of Tourism Research, 60, 80-96.

29. Couto, G., Castanho, R. A., Pimentel, P., Carvalho, C., Sousa, Á., \& Santos, C. (2020). The impacts of COVID-19 crisis over the tourism expectations of the Azores archipelago residents. Sustainability, 12(18), 7612.

30. Sims, C. A. (1980). Macroeconomics and reality. Econometrica: journal of the Econometric Society, 1-48.

31. Engle R. F., Ito T., Lin W-L. (1990). Meteor Showers or Heat Waves? Heteroskedastic Intra-Daily Volatility in the Foreign Exchange Market. Econometrica, 58, pp. 525-542.

32. Diebold, F. X., \& Yilmaz, K. (2012). Better to give than to receive: Predictive directional measurement of volatility spillovers. International Journal of forecasting, 28(1), 57-66.

33. Chamberlain, G. (1982), “Multivariate Regression Models for Panel Data”, Journal of Econometrics, 18 (1), 5-46.

34. Florens, J.-P. and Mouchart, M., (1982). “Note on Non-causality”, Econometrica, 50 (3), 583-591.

35. Engle, R. F., \& Granger, C. W. (1987). Co-integration and error correction: representation, estimation, and testing. Econometrica: journal of the Econometric Society, 251-276.

36. Davaajargal L. (2018). Dyindex. Eviews Add-ins.

37. Lubowa, D. (2016). The proposed single tourist visa in East Africa community: prospects and challenges. Eastern African Journal of Hospitality, Leisure and Tourism, 4(1), 52-73.

38. RETOSA (Regional Tourism Organisation of Southern Africa), 2009. The Tourist Visa (UNIVISA). -RETOSA. www.retosa.co.za/regional-initiatives/tourist-visa 23.05.2012 